\title{
Higher Education in Evening Courses in Brazil: History, Growth and Public Policies at the Beginning of the XXI Century
}

\author{
Armando Terribili Filho ${ }^{1, *}$, Iraíde Marques de Freitas Barreiro \\ ${ }^{1}$ FAAP , Fundação Armando Alvares Penteado, São Paulo (SP), Brazil \\ ${ }^{2}$ Marília, UNESP, Universidade Estadual Paulista, Marília (SP), Brazil
}

\begin{abstract}
There are three distinct and complementary objectives in this article in order to clarify the higher education outline in Brazil, specifically evening courses (classes are held on weekdays, generally from 7:00 pm to 10:30 pm) and thesecurrent sector policies. The first objective is to present a short historical overview on the establishment of evening courses in Brazil, including those in the higher education level, occurred on the middle of last century. The second objective is to demonstrate the growth of evening higher education in Brazil, considering that in 1998, of the 2.1 million college enrollments, $55.3 \%$ were enrolled in evening courses; in 2010, twelve years later, of the 5.4 million students enrolled, there were $63.5 \%$ enro lled in evening courses. This expansion is due to the growing need of many students who must work while attending college, to defray costs of the study as well as personal and family costs. The reality of the working student is hostile considering external factors, such as transport problems, public security and lack of legislation for flexible working hours. The third objective is to discuss current public policies to expand eveningopenings in public institutions which represent nowadays only $16.1 \%$ of the 3.4 million enrollments for evening classes, including federal $(6.8 \%)$, state $(7.0 \%)$ and municipal (2.3\%) institutions. In the third objective it is included the discussion of programs for scholarships and tuition loans. The methodology applied was to rescue historical in formation on the establishment and the expansion of evening courses in Brazil, analy zing the current general Brazilian polic ies and the specific ones from the State of São Paulo. The research results pointed to the importance of federal programs for scholarships and tuition loans for students from private institutions such as the 1,382,484 scholarships since 2004 (PROUNI Program) and the 847,000 tuition loans since 1999 (FIES Program). Important steps have been made by the Brazilian government. Considering that there are 3,987,424 enrollments in private institutions, the effectiveness of the programs for scholarships and tuition loans is still insufficient to meet the universal benefits for the student's needs. Evening courses became the real instrument of social inclusion for many Brazilian youths and must be expanded quantitatively and qualitatively, with aggressive public policies, including also, scholarships and tuition loans.
\end{abstract}

Keywords Higher Education Brazil, Evening Higher Education Brazil, Brazilian Public Policy, Evening Education Brazil

\section{Introduction}

The number of enrollments in the higher education in Brazil has had an exponential growth in the last 30 years, increasing from $1,377,286$ in 1980 to $5,449,120$ in 2010. This represents a numerical gro wth of $296 \%$, in other words, the number of enrollments has been almost quadruplicated. It is possible to allege that this is the result of the population growth. However, according to the census conducted by the Brazilian Institute of Geography and Statistics (IBGE), the population growth in this period was only $60 \%$, because the

\footnotetext{
* Correspondingauthor:

aterribili@faap.br (Armando Terribili Filho)

Published online at http://journal.sapub.org/edu

Copyright (C) 2012 Scientific \& Academic Publishing. All Rights Reserved
}

Brazilian population grew from 119 million in 1980 to 190.7 million in 2010[6].

Similarly, the evening higher education (classes are held on weekdays, generally from 7:00 pm to 10:30 pm) has been growing each passing year. The first statistical data were provided by the National Institute for Educational Studies and Research Anísio Teixeira (INEP) in 1991, whenenrollments in higher education in the country were 703,000 , representing $55.1 \%$ of total enrollments. In 2010 , according to Synopsis of Higher Education held by INEP there were $3,457,480$ enrollments in the country, representing $63.5 \%$ of total enrollments [8], [19].

The discussions in this article emphasize the role of the Brazilian government in relation to this growth, referring to two dimensions: (1) opening of federal institutions for evening courses, and (2) program to grant scholarships to 
private institutions through the University for All Program (PROUNI) initiated in 2005 and other public policies which caused the increase in the number of openings in higher education in the evening period.

Thus, the article has three distinct and complementary goals. The first is to present a quick historical review on theestablishment of evening courses in Brazil, including higher education, which occurred in the middle of last century. The second is to make evident the expansion of evening higher education in Brazil, considering that in 1998 of the 2.1 million college students in undergraduate attendance, 55.3\% were enrolled in evening courses; in 2010 (last census of Education Superior held annually in Brazil by INEP) of the 5.4 million students in higher education, there were $63.5 \%$ in evening courses. The last goal of the article is to discuss current public policies regarding the expansion of openings for evening courses, in public universities, which now represent only $16.1 \%$ of the 3.4 million enrollments for evening courses, including the federal $(6.8 \%)$, state $(7.0 \%)$ and municipal $(2.3 \%)$ universities.

The increase of enrollments in higher education is due to the combination of different factors owing to policy proposals for this sector, especially for federal universities, which indicate a greater presence of the State. Moreover, such policies should be accompanied by proposals that best serve different students in evening courses. In this context, it is increasing the number of students who need to work while attending an undergraduate course to defray study as well as personal expenses and as well as financially support their families, coupled with the hostile reality that the working student experiences in the educational environment, such as transport, security and lack of legislation for more flexible working hours.

\section{Evening Education: History and Current Situation}

The history of evening courses in Brazil originates in the Imperial Period (1822-1889), directly related to adult education, with varying objectives, such as literacy, disclosure to adults of their rights and responsibilities, professional training, etc. These schools emerged in the second half of the XIX century, but few have survived due to being undervalued[26].

In the early XX century, 50 evening schools were created in São Paulo to serve child workers. In 1919, there were 143 schools that served more than seven thousand students[1]. In the 1950's, middle school evening courses were installed in idle buildings which were used only during the day. Popular pressure for democratization of education in secondary level and higher education, lead to the establishment, in early 1960's of evening colleges (private) to respond to surplus students' claim - approved in college admission examinations and without openings to serve them[4]. In the 1970's and 1980's there was a strong expansion of courses in private institutions due to the university reform occurred in 1968[23].

Of the seven constitutions Brazil had, only the last one (1988) dealt with the evening teaching explicitly. The first constitution was made in the Empire of Brazil (1824), while the following four constitutions (1891, 1934, 1937 and 1946) were written by the Republic of the United States of Brazil. The constitutions of 1967 and 1988 were written as Federative Republic of Brazil. In the Constitution of 1988, the Article 208 establishes the conditions to bring into effect the duty of the State concerning education. The item VI of this article defines "the provision of regular evening courses suitable for the conditions of the student." The expression "suitable for the conditions of the student" leads to some different interpretations, including the one which says the student of this period presents particular conditions that should be covered by education[27].

The conditions of the higher education student who attends evening classes have been discussed in studies and researches, since the majority is composed of working students, the ones who work during the day and study in the evening, facing all kinds of difficulties. Firstly, physical difficulties, such as not eating properly, sleeping little and having little leisure. Secondly, there are mental, intellectual and psychic issues, since they face adversity to get to the college premises (inadequate public transport, traffic jam), public security problems, stress and pressure at work with constant delays and absences in classes, which impact negatively in the construction of knowledge.

Studies conducted[28] present the factors that cause delays and absences of students in evening higher education, causing a direct impact on the process of construction of students' knowledge.

Each year, there is an increasing concentration of enrollments for evening undergraduate courses. Table 1 shows the triennial evolution (since 1998) of the percentage representativeness of enrollments in evening higher education before the total enrollments between the two periods (day and evening courses). In 1998, the evening courses represented $55.3 \%$, in $2001,57.2 \%$, in $2004,58.6 \%$ in 2007 reaches $61.7 \%$, and in $2010,63.5 \%$.

Table 1. Evolution of the representativeness of enrollments in evening higher education in Brazil

\begin{tabular}{|c|c|c|c|c|}
\hline & \multicolumn{3}{|c|}{ Enrollments in Higher Education Courses- } & \\
\hline Yttending Ones & Day Courses & $\begin{array}{c}\text { Evening } \\
\text { Courses }\end{array}$ & $\begin{array}{c}\text { Representative } \\
\text { ness of } \\
\text { Evening } \\
\text { Courses (\%) }\end{array}$ \\
\hline 1998 & $2,125,958$ & 950,591 & $1,175,367$ & $55.3 \%$ \\
\hline 2001 & $3,030,754$ & $1,295,818$ & $1,734,936$ & $57.2 \%$ \\
\hline 2004 & $4,163,733$ & $1,709,385$ & $2,454,348$ & $58.9 \%$ \\
\hline 2007 & $4,880,381$ & $1,870,848$ & $3,009,533$ & $61.7 \%$ \\
\hline 2010 & $5,449,120$ & $1,991,640$ & $3,457,480$ & $63.5 \%$ \\
\hline
\end{tabular}

Sources:[8],[11],[14],[16],[19]

The three following tables (Tables 2, 3 and 4) show strong growth in openings in evening higher education 
courses due to the expansion of federal universities, together with the greater expansion of private higher education, encouraged by Brazilian policies. In Brazil, the courses offered by federal and state universities are completely exempt from tuition.

Table 2 shows the significant participation of private institutions in evening higher education with 2,902,241 enrollments, representing $53.3 \%$ of overall enrollments in the country.

Table 2. Distribution of Higher Education in Brazil by type of educational institution and period

\begin{tabular}{|c|c|c|c|c|c|}
\hline & Total & $\begin{array}{c}\text { Day } \\
\text { Courses }\end{array}$ & $\%$ & $\begin{array}{c}\text { Evening } \\
\text { Courses }\end{array}$ & $\%$ \\
\hline Public & $1,461,696$ & 906,457 & $16.6 \%$ & 555,239 & $10.2 \%$ \\
\hline Private & $3,987,424$ & $1,085,183$ & $19.9 \%$ & $2,902,241$ & $53.3 \%$ \\
\hline Total & $5,449,120$ & $1,991,640$ & - & $3,457,480$ & - \\
\hline
\end{tabular}

Source:[19]

Table 3 explains the distribution of enrollments for evening courses by type of educational institution, showing that in public universities there are 555,239 enrollments $(16.1 \%)$ whereas in private ones the enrollment rate is 2,902,241 (83.9\%). Enrollment rates for evening courses of public institutions is $6.8 \%$ for federal, $7.0 \%$ for state and $2.3 \%$ for municipal universities.

Table 3. Distribution of enrollments for evening courses by type of educational institution

\begin{tabular}{|c|c|c|}
\hline Type of Institution & Evening Courses & $\%$ \\
\hline Public Federal & 236,584 & $6.8 \%$ \\
\hline Public State & 240,087 & $7.0 \%$ \\
\hline Public Municipal & 78,568 & $2.3 \%$ \\
\hline Public Total & 555,239 & $16.1 \%$ \\
\hline Private Total & $2,902,241$ & $83.9 \%$ \\
\hline Total & $3,457,480$ & $100.0 \%$ \\
\hline
\end{tabular}

Source:[19]

It is worth mentioning that increases in enrollments in private institutions do not imply improvement in quality of education.

\section{The Specific Legislation in the State of Sao Paulo}

The Constitution of São Paulo (1989), through its Article 253 , guides the higher education system in state public institutions in São Paulo.Currently there are three state universities in São Paulo: UNESP -Universidade Estadual Paulista (Stateof São Paulo University), UNICAMP Universidade Estadual de Campinas (Campinas State University) and USP-Universidade de São Paulo (São Paulo University). To increase the number of openings, in accordance with this Constitution, standards of teaching quality and research development must be maintained. The single paragraph of the same Article 253 establishes that the state public universities must offer, for the evening courses, the number of at least one-third $(33.3 \%)$ of the total openings offered[24]. Table 4 presents data of the Synopsis of Higher Education in the State of São Paulo[18], which evidences the compliance with the state legislation.

The data highlight that São Paulo state universities meet the State of São Paulo legislation because of the 152,098 enrollments, $38.4 \%$ are offered for evening courses. However, this percentage is still far from the current demands of society, because $63.5 \%$ of enrollments in Brazil are for evening courses and in the State of São Paulo, this percentage is even higher: $73.2 \%[19]$. Moreover, there should be a percentage distribution for the evening courses by areas of knowledge, because most of the enrollments are concentrated in the area of humanities, rather than the biomed ical area[2].

Table 4. Representativeness of enrollments in evening higher education in São Paulo - 2010

\begin{tabular}{|c|c|c|c|c|}
\hline $\begin{array}{c}\text { Type of } \\
\text { Educational } \\
\text { Institution }\end{array}$ & Total & $\begin{array}{c}\text { Day } \\
\text { Courses }\end{array}$ & $\begin{array}{c}\text { Evening } \\
\text { Courses }\end{array}$ & $\begin{array}{c}\text { Representati } \\
\text { venessof } \\
\text { Evening } \\
\text { Courses (\%) }\end{array}$ \\
\hline Public Federal & 22,693 & 15,040 & 7,653 & $33.7 \%$ \\
\hline Public State & 152,098 & 93,718 & 58,380 & $38.4 \%$ \\
\hline Public Municipal & 37,244 & 8,458 & 28,786 & $77.3 \%$ \\
\hline Public Total & 212,035 & 117,216 & 94,819 & $44.7 \%$ \\
\hline Private Total & $1,262,481$ & 276,921 & 985,560 & $78.1 \%$ \\
\hline Overall total & $1,474,516$ & 394,137 & $1,080,379$ & $73.3 \%$ \\
\hline
\end{tabular}

Source:[19]

On the other hand, for the federal institutions there is no legislation that guarantees a minimum supply of openings for the evening courses. According to the 2010 census there are 833,934 enrollments in federal institutions, of which 236,584 are for the evening courses, representing $28.4 \%$ (Table 5). It can be seen a continuous growth on the representativeness of the evening period, in the number of enrollments from 1998 to 2010, since in 1998 it was $20.1 \%$ and in 2010 was $28.4 \%$.

Table 5. Enrollments in Federal Institutions

\begin{tabular}{|c|c|c|c|}
\hline Year & $\begin{array}{c}\text { Federal } \\
\text { (Total) }\end{array}$ & $\begin{array}{c}\text { Federal } \\
\text { (Evening Courses) }\end{array}$ & $\begin{array}{c}\text { Representativeness of } \\
\text { Evening Courses (\%) }\end{array}$ \\
\hline 1998 & 408,640 & 82,284 & $20.1 \%$ \\
\hline 2000 & 482,750 & 111,537 & $23.1 \%$ \\
\hline 2002 & 531,634 & 131,378 & $24.7 \%$ \\
\hline 2004 & 574,584 & 144,196 & $25.1 \%$ \\
\hline 2006 & 589,821 & 149,402 & $25.3 \%$ \\
\hline 2008 & 643,101 & 166,592 & $25.9 \%$ \\
\hline 2010 & 833,934 & 236,584 & $28.4 \%$ \\
\hline
\end{tabular}

Sources:[7],[10],[12],[14],[17],[19]

\section{Enrollments in Federal Institutions}

In Brazil there are 99 federal institutions of higher education of which 58 are universities, four are colleges and 
37 are IFs - Instituto Federal de Educação, Ciência e Tecnologia (Federal Institution of Education, Science and Technology) and CEFETs-Centro Federal de Educação Tecnológica (Federal Center of Technological Education). Total enrollments in Federal Institutions from 1998 up to 2010 increased $104.1 \%$ and in evening courses, this increase was $187.5 \%$ (Table 6). It can be said that total enrollments in federal institutions "has doubled" in these 12 years and for evening courses it "has tripled." The data highlight the effective action of public policy created by the federal government, with priority given to evening teaching.
However, when comparing the percentage of increase of enrollments in federal institutions to the percentage of increase in Brazilian education in general, it is observed that the overall increase $(194.2 \%)$ is higher than in federal institutions $(187.5 \%)$.

Furthermore, when analyzing the percentage of enrollments for evening courses in all federal institutions in relation to all enrollments in federal institutions in Brazil, it is noted that the "contribution" of evening courses has not been increasing, on the contrary, there is a slight decrease (7.0\% in 1998 and $6.8 \%$ in 2010).

Table 6. Enrollments in Federal Inst itut ions and the percentage contribution on overall numbers of Higher Educat ion in Brazil

\begin{tabular}{|c|c|c|c|c|c|}
\hline Year & Federal (Total) & Federal (Evening) & $\begin{array}{c}\text { Representativeness of } \\
\text { Evening Courses (\%) }\end{array}$ & $\begin{array}{c}\text { Evening Courses } \\
\text { (Total) }\end{array}$ & $\begin{array}{c}\text { Contribution on } \\
\text { Evening Courses (\%) }\end{array}$ \\
\hline 1998 & 408,640 & 82,284 & $20.1 \%$ & $1,175,367$ & $7.0 \%$ \\
\hline 2000 & 482,750 & 111,537 & $23.1 \%$ & $1,510,338$ & $7.4 \%$ \\
\hline 2002 & 531,634 & 131,378 & $24.7 \%$ & $2,003,755$ & $6.6 \%$ \\
\hline 2004 & 574,584 & 144,196 & $25.1 \%$ & $2,454,348$ & $5.9 \%$ \\
\hline 2006 & 589,821 & 149,402 & $25.3 \%$ & $2,847,670$ & $5.2 \%$ \\
\hline 2008 & 643,101 & 166,592 & $25.9 \%$ & $3,179,613$ & $5.2 \%$ \\
\hline 2010 & 833,934 & 236,584 & $28.4 \%$ & $3,457,480$ & $6.8 \%$ \\
\hline 1998 to 2010 & $104.1 \%$ & $187.5 \%$ & - & $194.2 \%$ & \\
\hline
\end{tabular}

Sources:[7],[10],[12],[14],[17],[19]

Table 7. Enrollments in Higher Education: Brazilt total and federal inst itutions $(1980-2010)$

\begin{tabular}{|c|c|c|c|c|c|}
\hline Year & Brazil total & $\begin{array}{c}\text { Federal } \\
\text { Institutions Total }\end{array}$ & $\begin{array}{c}\text { Federal } \\
\text { Representativeness (\%) }\end{array}$ & $\begin{array}{c}\% \text { Annual Growth } \\
\text { (Overall) }\end{array}$ & $\begin{array}{l}\% \text { Annual Growth } \\
\text { (Federal Institutions) }\end{array}$ \\
\hline 1980 & $1,377,286$ & 316,715 & $23.0 \%$ & - & - \\
\hline 1981 & $1,386,792$ & 313,217 & $22.6 \%$ & $0.7 \%$ & $-1.1 \%$ \\
\hline 1982 & $1,407,987$ & 316,940 & $22.5 \%$ & $1.5 \%$ & $1.2 \%$ \\
\hline 1983 & $1,438,992$ & 340,118 & $23.6 \%$ & $2.2 \%$ & $7.3 \%$ \\
\hline 1984 & $1,399,539$ & 326,199 & $23.3 \%$ & $-2.7 \%$ & $-4.1 \%$ \\
\hline 1985 & $1,367,609$ & 326,522 & $23.9 \%$ & $-2.3 \%$ & $0.1 \%$ \\
\hline 1986 & $1,418,196$ & 325,734 & $23.0 \%$ & $3.7 \%$ & $-0.2 \%$ \\
\hline 1987 & $1,470,555$ & 329,423 & $22.4 \%$ & $3.7 \%$ & $1.1 \%$ \\
\hline 1988 & $1,503,555$ & 317,831 & $21.1 \%$ & $2.2 \%$ & $-3.5 \%$ \\
\hline 1989 & $1,518,904$ & 315,283 & $20.8 \%$ & $1.0 \%$ & $-0.8 \%$ \\
\hline 1990 & $1,540,080$ & 308,867 & $20.1 \%$ & $1.4 \%$ & $-2.0 \%$ \\
\hline 1991 & $1,565,056$ & 320,135 & $20.5 \%$ & $1.6 \%$ & $3.6 \%$ \\
\hline 1992 & $1,535,788$ & 325,884 & $21.2 \%$ & $-1.9 \%$ & $1.8 \%$ \\
\hline 1993 & $1,594,668$ & 344,387 & $21.6 \%$ & $3.8 \%$ & $5.7 \%$ \\
\hline 1994 & $1,661,034$ & 363,543 & $21.9 \%$ & $4.2 \%$ & $5.6 \%$ \\
\hline 1995 & $1,759,703$ & 367,531 & $20.9 \%$ & $5.9 \%$ & $1.1 \%$ \\
\hline 1996 & $1,868,529$ & 388,987 & $20.8 \%$ & $6.2 \%$ & $5.8 \%$ \\
\hline 1997 & $1,945,615$ & 395,833 & $20.3 \%$ & $4.1 \%$ & $1.8 \%$ \\
\hline 1998 & $2,125,958$ & 408,640 & $19.2 \%$ & $9.3 \%$ & $3.2 \%$ \\
\hline 1999 & $2,369,945$ & 442,562 & $18.7 \%$ & $11.5 \%$ & $8.3 \%$ \\
\hline 2000 & $2,694,245$ & 482,750 & $17.9 \%$ & $13.7 \%$ & $9.1 \%$ \\
\hline 2001 & $3,030,754$ & 502,960 & $16.6 \%$ & $12.5 \%$ & $4.2 \%$ \\
\hline 2002 & $3,479,913$ & 531,634 & $15.3 \%$ & $14.8 \%$ & $5.7 \%$ \\
\hline 2003 & $3,887,022$ & 567,101 & $14.6 \%$ & $11.7 \%$ & $6.7 \%$ \\
\hline 2004 & $4,163,733$ & 574,584 & $13.8 \%$ & $7.1 \%$ & $1.3 \%$ \\
\hline 2005 & $4,453,156$ & 579,587 & $13.0 \%$ & $7.0 \%$ & $0.9 \%$ \\
\hline 2006 & $4,676,646$ & 589,821 & $12.6 \%$ & $5.0 \%$ & $1.8 \%$ \\
\hline 2007 & $4,880,381$ & 615,542 & $12.6 \%$ & $4.4 \%$ & $4.4 \%$ \\
\hline 2008 & $5,080,056$ & 643,101 & $12.7 \%$ & $4.1 \%$ & $4.5 \%$ \\
\hline 2009 & $5,115,896$ & 752,847 & $14.7 \%$ & $0.7 \%$ & $17.1 \%$ \\
\hline 2010 & $5,449,120$ & 833,934 & $15.3 \%$ & $6.5 \%$ & $10.8 \%$ \\
\hline
\end{tabular}

Sources:[8-19] 
Table 7 shows the total of annual enrollments in Brazil and in federal institutions for the years 1980 to 2010 , highlighting the annual representativeness before the overall. Thus, in 1980, total enrollment of federal institutions represented 23.0\% of the overall in Brazil and in 2010 represented $15.3 \%$. The two rightmost columns represent the annual increase percentage of enrollments in Brazil in federal institutions. It is seen that since 1995 the overall increase of enrollments is higher than in federal institutions, except for the last three years (2008, 2009 and 2010), when the percentage of increase of enrollments in federal institutions exceeded the overall percentage, provided that in 2007 it was $4.5 \%$ versus $4.1 \%$, in 2009 it was $17.1 \%$ versus $0.7 \%$ and in 2010 it was $10.8 \%$ versus $6.5 \%$.

The rates alternation and growth are connected to the historical background of Brazil in the process of augmentingthe possibilities and extension of higher education in the country by proposing public policies for the sector, especially since 1995. In this context, it is possible toidentify three different governmental management groups.Group 1 (1980-1994) covers the end of the Military Era and the beginning of the New Republic, under the presidents: JoãoFigueiredo-1979/1985, José Sarney-1985/ 1990, Fernando Collor de Mello-1990/92 and Itamar Franco - 1992/94. Group 2 (1995-2002) consists of two terms of Fernando Henrique Cardoso (FHC) and group 3 (2003-2010) by two terms of LuizInácio Lula da Silva.

Table 8 better explains this analys is when checking that the growth rates of group 1 are the lowest $(20.6 \%$ of total enrollments in the country and $14.8 \%$ of enrollments in federal institutions). Moreover, this period is the longest of the study (15 years). In groups 2 and 3 (periods of 8 years) there is substantial growth in both dimensions which have been analyzed. In FHC's government, the growth of enrollments in the country was $109.5 \%$ and $46.2 \%$ in federal institutions. In Lula's government the growth was $56.6 \%$ and $56.9 \%$, respectively.

Table 8. Enrollments in Higher Education in different governmental management periods (1980-2010)

\begin{tabular}{|c|c|c|c|c|}
\hline Period & Group & $\begin{array}{c}\text { President } \\
\text { (s) }\end{array}$ & $\begin{array}{c}\text { Growth } \\
\text { Total } \\
\text { Enrollments }\end{array}$ & $\begin{array}{c}\text { Growth } \\
\text { Federal } \\
\text { Enrollments }\end{array}$ \\
\hline 1980 to 1994 & 1 & several & $20.6 \%$ & $14.8 \%$ \\
\hline 1995 to 2002 & 2 & FHC & $109.5 \%$ & $46.2 \%$ \\
\hline 2003 to 2010 & 3 & Lula & $56.6 \%$ & $56.9 \%$ \\
\hline
\end{tabular}

Sources:[8-19].

Far from any attempt to make a value judg ment about the effectiveness of previous managements, based on some percentage, it is observed that FHC's government has a strong overall growth of enrollments. When he began his first term, there were $1,661,034$ enrollments in higher education in the country and when his second term ended, there were $3,479,913$ en rollments, in other words, this numbermore than doubled.

Lula's government, on the other hand, had a significant growth in enrollment in Federal Institutions because, when he took over in January 2003, there were 531,634 registrations and when he finished his second term there were 833,934 enrollments. In this period of eight years (2003-2010) 26 federal institutions were established (15 universities and 11 colleges, IFs and CEFETs) and policies favoring access to the current higher education were implemented. These are addressed below.

\section{Federal Policies to Expand Access to Higher Education}

\subsection{PROUNI - ProgramaUni versidade par a Todos (University for All Program)}

This program was created by the Federal Government in 2004 and institutionalized by Law No. 11096, dated January 13th, 2005, with the purpose of granting scholarships (partial and full) to undergraduate students in private institutions of higher education. It is intended for high school students from public institutions as well as private ones, who are provided with full scholarship, with per capita income of up to three minimum wages ${ }^{1}$. Candidates are selected by their results in ENEM - Exame Nacionaldo EnsinoMédio (National Secondary Education Examination). Created as a tool for assessing the completion of basic education, since its establishment ten years ago, it has been changing and now replaces the traditional college admission examination and became a gateway not only to federal but also to some state universities.

PROUNI benefited 1,382,484 students from 2005 to 2011 , as it is shown in Table 9. Of this total, $88 \%$ of beneficiaries are of students under "in class courses" modality and $12 \%$ of "distance learning" modality.

Figure 1 illustrates the growth in the process of granting scholarships of PROUNI in the period. Private education institutions which adhered to the PROUNI program benefited from the exemption of some federal taxes.

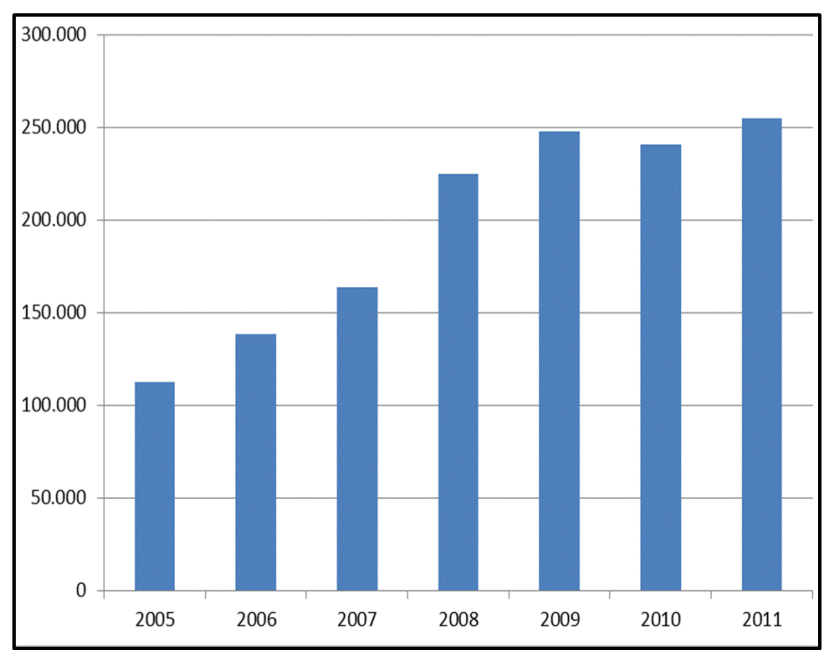

Figure 1. Grant of scholarships by PROUNI (2005-2011) Source:[22]

\footnotetext{
${ }^{1}$ The 2012 fed eral minimum wage is R $\$ 622.00$ (Brazilian Reais), equival ent to about US\$ 308.00
} 
Table 9. Grant of Scholarships by PROUNI

\begin{tabular}{c|c|c|c}
\hline Year & Full & Partial & Total \\
\hline 2005 & 71,905 & 40,370 & 112,275 \\
\hline 2006 & 98,698 & 39,970 & 138,668 \\
\hline 2007 & 97,631 & 66,223 & 163,854 \\
\hline 2008 & 99,495 & 125,510 & 225,005 \\
\hline 2009 & 153,126 & 94,517 & 247,643 \\
\hline 2010 & 125,090 & 115,351 & 240,441 \\
\hline 2011 & 129,672 & 124,926 & 254,598 \\
\hline Total & 775,617 & 606,867 & $1,382,484$ \\
\hline
\end{tabular}

Source:[22]

\subsection{FIES - Fundo de FinanciamentoEstudantil (Student Financing Fund)}

FIES is a MEC - Ministério da Educação (Ministry of Education) programdesigned to cover students enrolled in private institutions of higher education[3]. In 2010, FIES started operating on a new format, with a reduction in interest rates, allowing the student to request a loan at any time of the year.

Payment is made in three stages: use, grace phase and amortization (after withdrawal). In the first two stages, the student pays a minimum fee related to the interest on the loan. The grace stage lasts 18 months after graduation. The period required for amortization is calculated as if it were three times the financed period of the course, plus 12 months. Banks operating in FIES are: BB - Banco do Brasil (Bank of Brazil) - and CEF - CaixaEconômica Federal (a federal savings bank with many parallel functions). There are 1,400 educational institutions in the country participating of this program.

According to FIES statistics, the program registered 75,603 loans in 2010 and 152,406 in 2011. The goal for 2012 is to reach 200,000 loans. Students benefit from PROUNI with $50 \%$ and grants can finance the remaining tuition through FIES[20].

FIES, which was established in 1999, has had so far 847,000 beneficiaries, a figure that is considered by experts as being too low, on the basis of the government's goal of reaching the 10 million enrollments in 2020 according to the National Education Plan[21]. It must be highlighted that, according to the results of the last Census on Higher Education (2010), there were 4.4 million enrollments in undergraduate "in class courses" modality and 930 thousand in" distance learning" modality[19].

\subsection{Other Initiatives in Brazil: SiSU, UAB and REUNI}

The Unified System Selection (Sistema de SeleçãoUnific ada - SiSU) aims to select candidates for enrollment in public institutions of higher education that use their results from ENEM as the only phase for their selection process in order to replace the former college admission examination as selection processes. The selection is made by SiSU based on results of the candidates in ENEM. The process is conducted twice a year at the beginning of each semester, with no registration fee, and is handled by the Internet[25].
In the first semester of 2012, 95 institutions had joined SiSU, representing 108,552 openings distributed in 3,327 different courses.

Another federal government initiative is the Open University of Brazil (UniversidadeAberta do Brasil - UAB) which aims to train teachers and other education professionals in different areas. According to information on the website of the Ministry of Education, the goal of $\mathrm{UAB}$ is:

[...] The spread and development of educational methodologies to insert themes in areas such as youth and adults, environmental education, heritage education, education for human rights, education of ethnic-racial relations, gender and sexual orientation and current is sues in the daily practice of public and private basic education systems in Brazil[29].

The Restructuring and Expansion of Federal Universities Program (REUNI) has six dimensions: to expand the provision for higher education (an increase of openings for admission, with priority given to the evening period, reduction of dropout rates, and occupation of unfilled openings), to restructure academic curriculum, pedagogical renewal, intra and inter-institutional mobility, social commitment of the institution and support of postgraduate courses toward the development and qualitative improvement of undergraduate courses (REUNI, 2012). Information available on the website of REUNI states that, in 2012, 250 thousand openings will be created in the federal universities and 600 thousand in federal education institutes, almost doubling the current openings.

\section{Results and Discussion}

Evening Higher Education (classes are held on weekdays, generally from 7:00 $\mathrm{pm}$ to $10: 30 \mathrm{pm}$ ) has been providing young Brazilians with the possibility to work while attending their undergraduate course, a condition thatfor many of them is in fact a real need. The remuneration obtained by the youths who work allow them to pay for their course (totally or partially), personal expenses or to assist their families financially. The thought "study to work or work to study?" is increasingly present in the Brazilian reality, when one observes that at present $63.5 \%$ of the 5.4 million enrollments in higher education are for evening courses, remembering that little over a decade there were $55.3 \%$ of 2.1 million enrollments. Even with all the difficulties of student's daily life, such as problems with public transport, traffic chaos in large Brazilian cities, lack of public security, absence of a labor legislation for more flexible working hours for students, among others, make the working student a symbol of determination and commitment.

The enrollment openings in public institutions are still modest in view of the current demand, i.e., of the 3,457,480 enrollments for evening courses, only $16.1 \%$ are served by public federal, state and municipal institutions, representing 555,239 . The contribution of public institutions is 
distributed as follows: federal $(6.8 \%)$, state $(7.0 \%)$ and municipal $(2.3 \%)$. Private institutions comprise $83.9 \%$ of the total enrollments. In other words, roughly, it can be said that every five students who study during the evening, four are in private institutions.

There is the Brazilian government's effort to increase the number of openings in public institutions, through specific programs such as REUNI, which among other objectives, seeks to expand public educational institutions, greater availability of jobs, reduction of dropouts and enrollment for unfilled openings. While supply of openings remains far from the current demand, the federal government circumvents the situation allowing the enrollment of students in private institutions through PROUNI, granting full and partial scholarships to students from public school and who have low income, through FIES, another initiative that aims to enable the student to finance his/her undergraduate course, paying for it later (18 months after completion) in an extended deadline (three times the period financed plus 12 months). The PROUNI benefited 1.4 million students since its inception in 2005 until the end of 2011. FIES serves about 150-200 thousand students per year.

\section{Conclusions}

In a country with 190 million inhabitants and 5.4 million students enrolled in higher education in class courses there is no space or time for slow and modest investments in education. It is urgent that public universities must be created, the number of openings must be expanded and courses must be targeted to regional needs, universities must be better equipped and constantly updated, an extensive program of teacher training be implemented, an increase of the remuneration consistent with the responsibilities and knowledge, in order to enhance the professional and rescue the teacher's "social recognition".

The programs of scholarships and funding should be more daring and less bureaucratic, allowing not only the payment of tuition but also the development of other initiatives covering especially housing and food. Loans should not be restricted to in class courses, but need to be expanded for the distance learning modality, although it has a slight higher enrollment(930 thousand in 2010), has had an extremely significant percentage of annual growth and has been aimed to students who belong to lower classes, according to a research recently published.

If Brazil wants to become solidified as one of the major world economies, it is necessary to build a country underpinned in education as a first priority. It is unacceptable that the sixth world largest economy has the 84th Human Development Index[5] on the planet!

Brazilian higher education needs investments and political support transcending the squalid party colors. Educational plans and policies must be aggressive in order to create a fairer society in which a higher quality of life is within everyone's reach.Higher education in Brazil needs to get away from a professional training concentrated focus, and include education for citizenship, bringing together cultural and ethical dimensions.

\section{REFERENCES}

[1] ALMEIDA, Laurinda Ramalho de. Curso noturno: uma abordagem histórica. São Paulo: FDE, 1998.

[2] BARREIRO, Iraíde Marques de Freitas; TERRIBILI FILHO, Armando. Educação superior no período noturno no Brasil: políticas, intenções e omissões. Ensaio: Avaliação e Políticas Públicas em Educação, Rio de Janeiro, n. 54, p. 81-101, jan./mar., 2007.

[3] FIES - FUNDO DE FINANCIAMENTO ESTUDANTIL. Online Available: http://sisfiesportal.mec.gov.br/.

[4] FURLANI, Lucia Maria Teixeira. A claridade da noite: os alunos do ensino superior noturno. São Paulo: Cortez, 1998.

[5] G1. Brasil ocupa a $184^{\mathrm{a}}$. posição entre 187 países no IDH 2011. 02/1 1/2011. Online Available: http://g1.globo.com/ brasil/noticia/2011/11/brasil-ocupa-84-posicao-entre-187-pai ses-no-idh-2011.html.

[6] IBGE - INSTITUTO BRASILEIRO DE GEOGRAFIA E EST ATÍSTICA. Sinop se do CensoDemográfico 2010.

[7] Inep - Instituto Nacional De Estudos E Pesquisas Educacionais Anísio Teixeira. Sinopse estatística da educação superior 1998. Brasília: INEP, 1999.

[8] INEP - INSTITUTO NACIONAL DE ESTUDOS E PESQUISAS EDUCACIONAIS ANÍSIO TEIXEIRA. Evolução da Edu cação Sup erior-Graduação. Anos 1980-1998. Brasília: INEP, 2000a.

[9] INEP - INSTITUTO NACIONAL DE ESTUDOS E PESQUISAS EDUCACIONAIS ANÍSIO TEIXEIRA. Sinopse estatística da educação sup erior 1999. Brasília: INEP, 2000b.

[10] INEP - INSTITUTO NACIONAL DE ESTUDOS E PESQUISAS EDUCACIONAIS ANÍSIO TEIXEIRA. Sinopse estatística da educação sup erior 2000. Brasília: INEP, 2001.

[11] INEP - INSTITUTO NACIONAL DE ESTUDOS E PESQUISAS EDUCACIONAIS ANÍSIO TEIXEIRA. Sinop se estatística da educação sup erior 2001. Brasília: INEP, 2002.

[12] INEP - INSTITUTO NACIONAL DE ESTUDOS E PESQUISAS EDUCACIONAIS ANÍSIO TEIXEIRA. Sinopse estatística da educação sup erior 2002. Brasília: INEP, 2003.

[13] INEP - INSTITUTO NACIONAL DE ESTUDOS E PESQUISAS EDUCACIONAIS ANÍSIO TEIXEIRA. Sinopse estatística da educação sup erior 2003. Brasília: INEP, 2004.

[14] INEP - INSTITUTO NACIONAL DE ESTUDOS E PESQUISAS EDUCACIONAIS ANÍSIO TEIXEIRA. Sinopse estatística da educação sup erior 2004. Brasília: INEP, 2005 . 
[15] INEP - INSTITUTO NACIONAL DE ESTUDOS E PESQUISAS EDUCACIONAIS ANÍSIO TEIXEIRA. Sinopse estatística da educação sup erior 2005. Brasília: INEP, 2006.

[16] INEP - INSTITUTO NACIONAL DE ESTUDOS E PESQUISAS EDUCACIONAIS ANÍSIO TEIXEIRA. Sinopse estatística da educação sup erior 2007. Brasília: INEP, 2008.

[17] INEP - INSTITUTO NACIONAL DE ESTUDOS E PESQUISAS EDUCACIONAIS ANÍSIO TEIXEIRA. Sinopseestatística da educação sup erior 2008. Brasília: INEP, 2009.

[18] INEP - INSTITUTO NACIONAL DE ESTUDOS E PESQUISAS EDUCACIONAIS ANÍSIO TEIXEIRA. Sinop seestatística da educação sup erior 2009. Brasília: INEP, 2010.

[19] INEP-INSTITUTO NACIONAL DE ESTUDOS E PESQUISAS EDUCACIONAIS ANÍSIO TEIXEIRA. Sinop seestatística da educação sup erior 2010. Brasília: INEP, 2011.

[20] INFOENEM. Regras e números do FIES. Online Available: http://www.infoenem.com.br/regras-e-numeros-do-fies/.

[21] LEITE, Priscilla. A chave da expansão. Revista Ensino Superior. São Paulo. n. 162, p. 24-28, mar. 2012.

[22] PROUNI - Programa Universidade para Todos. Dados e Estatísticas. Online Available: http://siteprouni.mec. gov.br/i ndex.php?option $=$ com_content $\&$ view $=$ article $\&$ id $=137$ :quadr os-informativos \&catid $=26$ :dados-e-estaticas \&Itemid $=147$

[23] SAMPAIO, Helena Maria Sant'Ana. Ensino superior no Brasil: o setor privado. São Paulo: Fapesp/Hucitec, 2000.

[24] SÃO PAULO. Constituição (1989). Constituição do Estado de São Paulo. Diário Ofícial do Estado de São Paulo, São Paulo, 6 out. 1989.

[25] SiSU - Sistema de Seleção Unificada. Online Available: http://sisu.mec.gov.br/.

[26] TERRIBILI FILHO, Armando; NERY, Ana Clara Bortoleto. Ensino superior noturno no Brasil, história, atores e políticas. RBPAE - Revista Brasileira de Política e Administração da Educação. v. 25, n. 1, jan./abr., 2009, p.61-82.

[27] TERRIBILI FILHO, Armando; RAPHAEL, Hélia Sônia. Ensino Superior Noturno: problemas, perspectivas e propostas. Marília: Fundepe, 2009.

[28] TERRIBILI FILHO, Armando; RAPHAEL, Hélia Sônia. Fatores de atrasos e faltas do estudante do ensino superior noturno: a perda de aulas, de provas e o impacto no seu aproveitamento e em avaliações. Revista da Rede de Avaliação Institucional da Educação Superior, Campinas, v. 10, n. 2, p. 117-135, jun. 2005.

[29] UAB - Universidade Aberta do Brasil. Programas e ações. Online Available: http://p ortal.mec.gov.br/index.php?option $=$ com_content $\&$ view $=$ article \&id=12265\&Itemid $=823$. 